University of Nebraska - Lincoln

DigitalCommons@University of Nebraska - Lincoln

Agronomy \& Horticulture -- Faculty Publications

Agronomy and Horticulture Department

January 1983

\title{
Binding of Phosphorylated Effectors by Active and Inactive Forms of Ribulose-1, 5-bisphosphate Carboxylase
}

Douglas B. Jordan

University of Nebraska-Lincoln

Raymond Chollet

University of Nebraska-Lincoln, rchollet1@unl.edu

William L. Ogren

University of Illinois, Urbana, Illinois

Follow this and additional works at: https://digitalcommons.unl.edu/agronomyfacpub

Part of the Plant Sciences Commons

Jordan, Douglas B.; Chollet, Raymond; and Ogren, William L., "Binding of Phosphorylated Effectors by Active and Inactive Forms of Ribulose-1, 5-bisphosphate Carboxylase" (1983). Agronomy \& Horticulture -Faculty Publications. 123.

https://digitalcommons.unl.edu/agronomyfacpub/123

This Article is brought to you for free and open access by the Agronomy and Horticulture Department at DigitalCommons@University of Nebraska - Lincoln. It has been accepted for inclusion in Agronomy \& Horticulture -Faculty Publications by an authorized administrator of DigitalCommons@University of Nebraska - Lincoln. 


\title{
Binding of Phosphorylated Effectors by Active and Inactive Forms of Ribulose-1,5-bisphosphate Carboxylase ${ }^{\dagger}$
}

\author{
Douglas B. Jordan, Raymond Chollet, ${ }^{*}$ and William L. Ogren
}

ABSTRACT: Activation of ribulose-1,5-bisphosphate carboxylase by $\mathrm{CO}_{2}$ and $\mathrm{Mg}^{2+}$ is slow and reversible. At subsaturating concentrations of $\mathrm{CO}_{2}$ and $\mathrm{Mg}^{2+}$, positive effectors increase and negative effectors decrease the amount of active enzyme at equilibrium. Preequilibrium experiments indicated that both positive and negative effectors inhibit the rates of enzyme activation and deactivation. Greater than $99 \%$ inhibition of the activation and deactivation rates was observed at high effector concentrations, indicating that the binding and release of the activators $\mathrm{CO}_{2}$ and $\mathrm{Mg}^{2+}$ occur only with effector-free enzyme. The deactivation rate $K_{\mathrm{i}}$ values for the negative effector ribose 5-phosphate and the positive effectors inorganic phosphate, fructose 1,6-bisphosphate, and 6-phosphogluconate were smaller than the corresponding activation rate $K_{\mathrm{i}}$ values by factors of $2,6,25$, and 670 , respectively. Thus, phosphorylated effectors impede deactivation more than activation. Equilibrium binding studies indicated that the active and in- active enzyme forms have similar affinities for the positive effectors inorganic phosphate $\left(K_{\mathrm{D}}=650 \mu \mathrm{M}\right)$ and fructose bisphosphate $\left(K_{\mathrm{D}}=11 \mu \mathrm{M}\right)$. The positive effector 3phosphoglycerate was bound with greater affinity by the inactive enzyme $\left(K_{\mathrm{D}}=25 \mu \mathrm{M}\right)$ than by the active enzyme $\left(K_{\mathrm{D}}\right.$ $=76 \mu \mathrm{M})$. Thus, preferential binding of positive effectors to the active enzyme form is not responsible for the enhancement of enzyme activation at equilibrium. The promotion of activation by positive effectors is mediated by altering the relative rates of activation and deactivation to favor active enzyme. Equilibrium binding studies indicated that the inactive enzyme had a much greater affinity for ribose 5-phosphate $\left(K_{\mathrm{D}}=42\right.$ $\mu \mathrm{M})$ than did the active enzyme $\left(K_{\mathrm{D}}=480 \mu \mathrm{M}\right)$. Preferential binding of this negative effector to inactive enzyme exceeds its stabilizing effect on the active enzyme form and thus causes an overall reduction of activation at equilibrium.
$\mathbf{R}$ quires the addition of $\mathrm{CO}_{2}$ and a divalent metal ion in forming an activated enzyme complex capable of catalyzing the carboxylation and oxygenation of RuBP ${ }^{1}$ (Lorimer et al., 1976). The kinetics of this process have been well characterized for several RuBPCase enzymes purified from microbial and plant sources (Badger, 1980; Christeller \& Laing, 1978; Laing \& Christeller, 1976). The rate-limiting step in $\mathrm{CO}_{2} / \mathrm{Me}^{2+} \mathrm{ac}-$ tivation is carbamate formation at a lysine residue (Lys-201) on the 56-kDa catalytic subunit of the enzyme (Lorimer, 1981; Lorimer \& Miziorko, 1980), and this is followed by rapid

\footnotetext{
${ }^{\dagger}$ From the Department of Agricultural Biochemistry, University of Nebraska-Lincoln, Lincoln, Nebraska 68583-0718 (D.B.J. and R.C.), the Agronomy Department, University of Illinois, Urbana, Illinois 61801 (D.B.J. and W.L.O.), and the U.S. Department of Agriculture, Agricultural Research Service, Urbana, Illinois 61801 (W.L.O.). Received December 22, 1982. Research sponsored in part by Grant 78-59-23110-1-119-1 from the USDA Competitive Research Grants Office (R.C.). Published as Paper No. 7046, Journal Series, Nebraska Agricultural Experiment Station.
}

addition of the metal cofactor as shown in eq 1 .

$$
\underset{\text { inactive }}{\mathrm{E}} \stackrel{\text { slow }}{\rightleftharpoons} \mathrm{E}-\mathrm{CO}_{2} \stackrel{\text { fast }}{\rightleftharpoons} \mathrm{E}-\mathrm{CO}_{2}-\mathrm{Me}^{2+}
$$

Although the mechanisms of activation and inhibition of RuBPCase by sugar phosphates and other anions have received considerable attention, these processes are not well resolved. Because of their potential regulatory role in vivo, chloroplast metabolites such as 6-P-gluconate, FBP, inorganic phosphate, and NADPH have been of primary interest. Several sugar phosphates enhance the activation state of RuBPCase which is partially activated with respect to $\mathrm{CO}_{2}$ and $\mathrm{Mg}^{2+}$, while other sugar phosphates lower the activation state of the enzyme

${ }^{1}$ Abbreviations: RuBP, ribulose 1,5-bisphosphate; RuBPCase, ribulose-1,5-bisphosphate carboxylase; CABP, 2-carboxyarabinitol 1,5-bisphosphate; FBP, fructose 1,6-bisphosphate; Bicine, $N, N$-bis(2-hydroxyethyl)glycine; $\mathrm{P}$, phosphate; $\mathrm{kDa}$, kilodalton; EDTA, ethylenediaminetetraacetic acid. 
(Hatch \& Jensen, 1980; McCurry et al., 1981). In addition to the effects on $\mathrm{CO}_{2} / \mathrm{Mg}^{2+}$ activation, most of these phosphorylated compounds inhibit the carboxylase reaction competitively with respect to RuBP. Nevertheless, several studies have indicated that interactions with a separate allosteric site account for the activation effects observed (Chu \& Bassham; 1975; Vater \& Salnikow, 1979). More recent interpretations have suggested that the effectors bind to the catalytic site and that the activation state of the enzyme is modulated by altering the equilibrium in the $\mathrm{CO}_{2} / \mathrm{Me}^{2+}$-activation process (Badger \& Lorimer, 1981; McCurry et al., 1981). In this view, positive effectors bind to the activated species more tightly than to the inactive enzyme and negative effectors act in an opposite fashion. Thus, the equilibrium of eq 1 is driven to the right or left by differential effector binding to the catalytic site of the active and inactive enzyme forms. There is no requirement for an allosteric site in this model. Evidence that the effectors bind to the catalytic site is drawn from the observation that they are linear competitive inhibitors of the carboxylase reaction with respect to RuBP and from studies which demonstrated that 6-P-gluconate and NADPH are prevented from binding to the active enzyme form if the active site is blocked by the tightly bound transition-state analogue CABP (Badger \& Lorimer, 1981).

Inactive enzyme binds and is stabilized by the substrate RuBP (Wishnick et al., 1970; Laing \& Christeller, 1976), but interactions of the inactive enzyme with phosphorylated effectors have not been examined. In this paper we report the binding and stabilization of the inactive enzyme form by several phosphorylated compounds. The hypothesis that the mechanism of effector-enhanced activation depends on the greater affinity of the active enzyme form for positive effectors was tested directly and rejected for a model in which these ligands alter the relative rates of activation and deactivation to favor the active enzyme form.

\section{Experimental Procedures}

\section{Materials}

RuBPCase was purified from spinach (Spinacea oleracea L.) and perennial ryegrass (Lolium perenne L.) leaves (Jordan \& Ogren, 1981b). The enzyme was stored in 55\% saturated ammonium sulfate at $2{ }^{\circ} \mathrm{C}$ or converted to frozen pellets in liquid $\mathrm{N}_{2}$ (Hall et al., 1981). Prior to use, enzyme was dialyzed $12-16 \mathrm{~h}$ at $2{ }^{\circ} \mathrm{C}$ against 1000 volumes of $50 \mathrm{mM}$ Bicine$\mathrm{NaOH}$ and $0.2 \mathrm{mM} \mathrm{Na}{ }_{2}$ EDTA, pH 8.0 (buffer A). Buffer A was adjusted with $\mathrm{NaOH}$ to $\mathrm{pH} 7.7$ at $24^{\circ} \mathrm{C}$. At $2{ }^{\circ} \mathrm{C}$, the same buffer was $\mathrm{pH}$ 8.0. RuBP was synthesized from ribose 5-P (Horecker et al., 1956) and purified as described (Jordan \& Ogren, 1981a). CABP was prepared and purified by the procedure of Pierce et al. (1980). $\left[1-{ }^{14} \mathrm{C}\right]$ Glycerate 3-P was prepared enzymically from RuBP and purified by ionexchange chromatography with a $\mathrm{HCO}_{2} \mathrm{H}$ gradient (Jordan \& Ogren, 1981a). Other sugar phosphates were obtained from Sigma Chemical Co. $\mathrm{NaH}^{14} \mathrm{CO}_{3}$ was from Amersham and New England Nuclear; [U-14 C]FBP was from Amersham; $\left[\mathrm{U}-{ }^{14} \mathrm{C}\right]$ ribose 5-P was from Schwarz/Mann. $\left[{ }^{32} \mathrm{P}\right] \mathrm{Phosphate}$ was a generous gift from Dr. D. R. Ort.

\section{Methods}

Activation Studies. Effector inhibition of the activation rate was studied by preincubating inactive enzyme in buffer $A$ with an effector and air levels of $\mathrm{CO}_{2}$ for 1 min prior to initiating activation with the addition of $10 \mathrm{mM} \mathrm{MgCl}$. At time intervals following the addition of $\mathrm{Mg}^{2+}$, aliquots of the enzyme solution were removed for the measurement of RuBPCase activity. The laboratory air concentration of $\mathrm{CO}_{2}(\sim 10 \mu \mathrm{M})$ was used in most activation experiments. This gave reproducible results, and the low $\mathrm{CO}_{2}$ concentration provided slow rates of activation which facilitated the measurement of initial rates. Activation rates were measured at 2 or $24^{\circ} \mathrm{C}$. At equilibrium, spinach RuBPCase was about $25 \%$ activated at $24^{\circ} \mathrm{C}$ in buffer $\mathrm{A}, \mathrm{pH} .7 .7,10 \mathrm{mM} \mathrm{MgCl}_{2}$, and air levels of $\mathrm{CO}_{2}$, and it was about $35 \%$ activated at $2{ }^{\circ} \mathrm{C}$ in buffer $\mathrm{A}, \mathrm{pH}$ $8.0,10 \mathrm{mM} \mathrm{MgCl}_{2}$, and air levels of $\mathrm{CO}_{2}$. Control experiments in which an effector (ribose 5-P, 6-P-gluconate, FBP, or phosphate) was added simultaneously with $\mathrm{Mg}^{2+}$ to inactive enzyme gave nearly identical initial rates of activation as when the effector was preincubated with inactive enzyme for $1 \mathrm{~min}$ prior to the addition of $\mathrm{Mg}^{2+}$. The rate of deactivation was measured at 2 or $24^{\circ} \mathrm{C}$ as described under Results.

RuBPCase assays were conducted at $25^{\circ} \mathrm{C}$. Enzyme aliquots were added to reaction mixtures containing $3 \mathrm{mM}$ $\mathrm{NaH}^{14} \mathrm{CO}_{3}(4 \mathrm{Ci} / \mathrm{mol}), 0.5 \mathrm{mM} \mathrm{RuBP}, 10 \mathrm{mM} \mathrm{MgCl}$, and $50 \mathrm{mM}$ Bicine, $\mathrm{pH} 8.3$, in $1.0 \mathrm{~mL}$. Assays were terminated after $20 \mathrm{~s}$ by the addition of $0.5 \mathrm{~mL}$ of $3 \mathrm{M} \mathrm{HCO}_{2} \mathrm{H}$ in methanol. After the samples were dried, ${ }^{14} \mathrm{C}$ incorporation was determined by liquid scintillation spectroscopy. The RuBP concentration in the assay mixture $(0.5 \mathrm{mM})$ was sufficient to prevent significant competitive inhibition of activity by carry-over of effector with the enzyme aliquot. No more than $3 \%$ inhibition of RuBPCase activity can be attributed to effector carry-over from the preincubation mixtures to the assay mixtures. The specific activity of spinach and ryegrass RuBPCases used for these experiments was between 1.2 and 2.0 units $/ \mathrm{mg}$ of protein at $25^{\circ} \mathrm{C}$ and saturating substrate concentrations. One unit of RuBPCase activity is defined as $1 \mu \mathrm{mol}$ of ${ }^{14} \mathrm{CO}_{2}$ fixed $/ \mathrm{min}$. Protein concentration $(\mathrm{mg} / \mathrm{mL})$ was estimated by multiplying the $A_{280 \mathrm{~nm}}^{1 \mathrm{~cm}}$ by 0.61 for spinach RuBPCase and by 0.65 for the ryegrass enzyme (Rejda et al., 1981). The molecular mass of RuBPCase used for calculations was $560 \mathrm{kDa}$ /holoenzyme and $70 \mathrm{kDa} /$ enzyme protomer. All lines were fitted by using least-squares regression analysis.

Binding Studies. Inorganic phosphate binding was measured at $4^{\circ} \mathrm{C}$ by using $\left[{ }^{32} \mathrm{P}\right]$ phosphate and the rate of dialysis technique (Colowick \& Womack, 1969). A flow-dialysis apparatus was constructed from Plexiglass with chamber diameters of $1 \mathrm{~cm}$. The upper chamber held $3 \mathrm{~mL}$ and the lower chamber, $0.5 \mathrm{~mL}$. The upper chamber was stirred with a magnetic stirring bar. Flow was rapid $(3 \mathrm{~mL} / \mathrm{min})$ through the lower chamber so stirring was not needed. Less than $5 \%$ of the radioactive label in the upper chamber was lost during an experiment. Inactive spinach RuBPCase $(38 \mathrm{mg})$ was incubated in the upper chamber with $0.25 \mathrm{mM}\left[{ }^{32} \mathrm{P}\right]$ phosphate $(160 \mathrm{Ci} / \mathrm{mol})$ in buffer $\mathrm{A}, \mathrm{pH} 8.0$, in a volume of $1 \mathrm{~mL}$. Active enzyme incubations included $10 \mathrm{mM} \mathrm{MgCl}$ or $10 \mathrm{mM} \mathrm{MgCl} 2$ and $20 \mathrm{mM} \mathrm{NaHCO}$. A high enzyme concentration was necessary in order to obtain a large fraction of the total phosphate in the bound form $(\sim 60 \%)$ at ligand concentrations below the $K_{\mathrm{D}}$. Buffer flowing through the lower chamber was collected at $1-\mathrm{min}$ intervals, and ${ }^{32} \mathrm{P}$ radioactivity was determined by liquid scintillation spectroscopy. The addition of $5-\mu \mathrm{L}$ aliquots of unlabeled phosphate to the upper chamber resulted immediately in an increased rate of $\left.{ }^{32} \mathrm{P}\right]$ phosphate release through the dialysis membrane. The rate of ${ }^{32} \mathrm{P}$ release reached a plateau $2-3 \mathrm{~min}$ after the addition of unlabeled phosphate, and this level was maintained until another addition was made. Between five and eight phosphate additions were made to each incubation. The final addition brought the concentration of phosphate in the upper chamber to 12-15 $\mathrm{mM}$, leaving more than $95 \%$ of the $\left[{ }^{32} \mathrm{P}\right]$ phosphate in the unbound form so that the maximum rate of ${ }^{32} \mathrm{P}$ release could 
be determined. Free exchange of phosphate from the enzyme was verified by gel filtration on a $1 \times 19 \mathrm{~cm}$ Sephadex G-25 column equilibrated with buffer $A$. Virtually no ${ }^{32} \mathrm{P}$ radioactivity was retained by protein after gel filtration.

Binding of $\left[{ }^{32} \mathrm{P}\right]$ phosphate, $\left[{ }^{14} \mathrm{C}\right] \mathrm{FBP},\left[{ }^{14} \mathrm{C}\right]$ ribose 5-P, and $\left[{ }^{14} \mathrm{C}\right]$ glycerate $3-\mathrm{P}$ was studied at 2 or $24^{\circ} \mathrm{C}$ by using a gel filtration method (Hummel \& Dreyer, 1952). A Sephadex G-75 column $(1 \times 19 \mathrm{~cm})$ was equilibrated with incubation buffer containing the specified concentration of labeled ligand by passing approximately $50 \mathrm{~mL}$ of buffer through the column. Separate columns were used for active and inactive enzymes. The flow rates were about $25 \mathrm{~mL} / \mathrm{h}$. Enzyme was preincubated $15 \mathrm{~min}$ in column buffer before application of a $0.4-\mathrm{mL}$ aliquot to the column. Preincubations of $1 \mathrm{~h}$ gave the same binding results with each ligand. When ligand binding by the inactive enzyme was studied under $\mathrm{CO}_{2}$-free conditions, the preincubation and gel filtration steps were conducted with $\mathrm{CO}_{2}$-free buffers under a continuous flow of $\mathrm{N}_{2}$. The column eluants were fractionated by a drop counter. Fractions (18 drop) containing the peak and the trough were well separated by a plateau region. The integrated values of the peaks and troughs were within $10 \%$ of being equal. Binding to the active and inactive enzyme forms was always studied in the same experiment using the same enzyme preparation in order to make a valid comparison between the binding characteristics of the two enzyme forms.

The amount of phosphorylated ligand complexed with $\mathrm{Mg}^{2+}$ was estimated by using the following stability constants for the respective $\mathrm{Mg}^{2+}$ complexes: Bicine, $14 \mathrm{M}^{-1}$ (Chaberek et al., 1953); inorganic phosphate, $60 \mathrm{M}^{-1}$ (Frey \& Stuehr, 1972); FBP, $550 \mathrm{M}^{-1}$ (McGilvery, 1965); glycerate 3-P, $100 \mathrm{M}^{-1}$ (Larsson-Răznikiewicz, 1972); ribose 5-P, $50 \mathrm{M}^{-1}$ (Frey \& Stuehr, 1972). EDTA was considered to be fully saturated with two molecules of $\mathrm{Mg}^{2+}$. In buffer $\mathrm{A}$, at a total $\mathrm{Mg}^{2+}$ concentration of $10 \mathrm{mM}$ and low concentrations of phosphorylated ligand, the $\mathrm{Mg}^{2+}$-ligand complex was estimated to comprise the following percentages of the total ligand concentrations: phosphate, $26 \%$; FBP, $80 \%$; glycerate $3-\mathrm{P}, 43 \%$; ribose 5-P, 26\%. Because of the large calculated values for $\mathrm{Mg}^{2+}$ complexing and the uncertainty of the calculated values under the experimental conditions employed, control experiments were devised to minimize the differences between active and inactive enzyme binding conditions. The controls are described under Results.

\section{Results}

Stabilization of Active and Inactive Enzyme Forms by $R U B P$. In the sections that follow, we report that the interactions between phosphorylated ligands and RuBPCase are similar to those observed between the enzyme and substrate RuBP. For this reason, we begin by summarizing the effects of RuBP on enzyme activation. In the higher plant-type RuBPCase, $\mathrm{CO}_{2} / \mathrm{Mg}^{2+}$-dependent activation and deactivation rates are decreased in the presence of RuBP (Laing \& Christeller, 1976). Our experiments confirmed these observations. We found, for example, that when fully active enzyme was diluted 50 -fold into $\mathrm{CO}_{2} / \mathrm{Mg}^{2+}$-free medium at $\mathrm{pH} 8.0$ and $2{ }^{\circ} \mathrm{C}$, the ensuing rate of deactivation was inhibited by about $90 \%$ if the dilution medium contained either 50 or 250 $\mu \mathrm{M} \mathrm{RuBP}$. Alternatively, when inactive enzyme was preincubated in the presence of $80 \mu \mathrm{M}$ RuBP before $\mathrm{CO}_{2} / \mathrm{Mg}^{2+}$ activation was initiated, the rate of activation at $\mathrm{pH} 8.0$ and $2{ }^{\circ} \mathrm{C}$ was inhibited by more than $99 \%$ in comparison to the rate observed when RuBP preincubation was omitted.

On the basis of the nearly complete inhibition observed in the presence of $\mathrm{RuBP}$, it is thought that the RuBP-bound

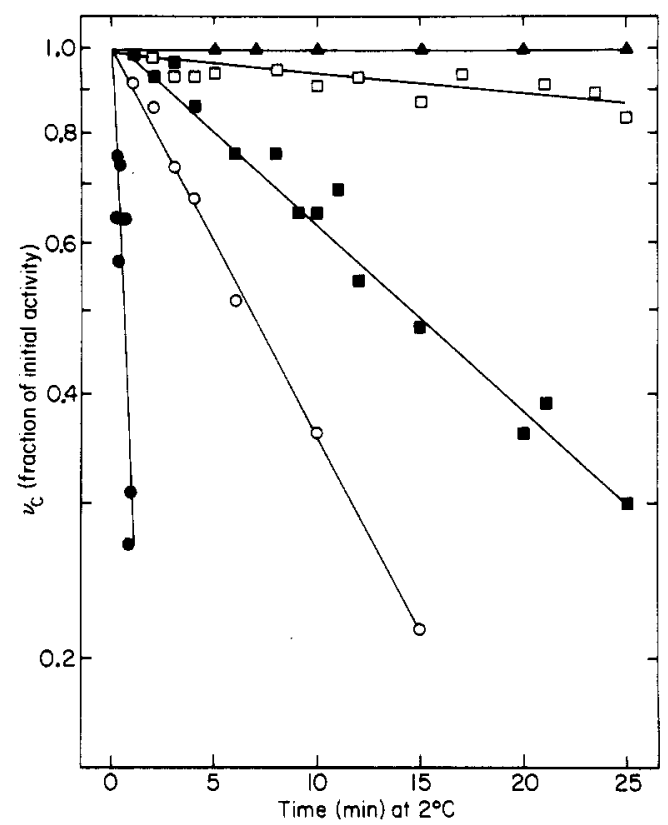

FIGURE 1: Effector stabilization of the active form of spinach RuBPCase. Enzyme $(18.0 \mathrm{mg} / \mathrm{mL})$ was activated $5 \mathrm{~h}$ at $2{ }^{\circ} \mathrm{C}$ in 50 $\mathrm{mM}$ Bicine, $0.2 \mathrm{mM}$ EDTA, $10 \mathrm{mM} \mathrm{MgCl}$, and $10 \mathrm{mM} \mathrm{NaHCO}_{3}$, $\mathrm{pH}$ 8.0. At time zero, $50 \mu \mathrm{L}$ of activated enzyme was diluted into

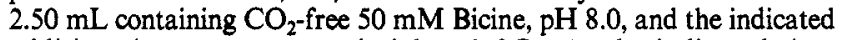
additions in a serum-capped vial at $2^{\circ} \mathrm{C}$. At the indicated time intervals after dilution, $10-\mu \mathrm{L}$ aliquots were removed to determine RuBPCase activity. The ratio $\left(\nu_{\mathrm{c}}\right)$ of RuBPCase activity at time $t$ to the initial RuBPCase activity is plotted vs. the time after dilution. Additions to the dilution medium were none $(\bullet), 1 \mathrm{mM}$ ribose 5 -P (O), $10 \mathrm{mM}$ inorganic phosphate ( $\square$ ), $1 \mathrm{mM}$ FBP (ם), and $0.1 \mathrm{mM}$ 6-P-gluconate $(\mathbf{\Delta})$.

enzyme is incapable of interconverting between the active and inactive forms as expressed by eq 2 :

$$
\begin{aligned}
& E \stackrel{\text { slow }}{\rightleftharpoons} \text { ECM } \\
& 11 \\
& \text { EF ECMF }
\end{aligned}
$$

where $\mathrm{E}$ represents enzyme, $\mathrm{C}$, activator $\mathrm{CO}_{2}, \mathrm{M}$, metal activator, and $F$, effector (in this case, RuBP). The enzyme species $\mathrm{E}$ and EF are inactive, while ECM and ECMF are active in the carboxylase assay used here. In this model, exchange of activator $\mathrm{CO}_{2}$ and $\mathrm{Mg}^{2+}$ does not occur when either active or inactive enzyme is fully saturated with RuBP; thus there is no direct interconversion between enzyme forms EF and ECMF in eq 2.

Stabilization of Enzyme Forms by Other Phosphorylated Compounds. Phosphorylated ligands which increase the activation state of RuBPCase are thought to do so by binding at the $\mathrm{RuBP}$ site of the active enzyme and shifting the equilibria of eq 1 to the right (Badger \& Lorimer, 1981; McCurry et al., 1981). If the activating properties of these positive effectors are explained by the equilibria of eq 2 , then these ligands should mimic the effects observed with RuBP. Stabilization of the active enzyme form by 6-P-gluconate and NADPH was demonstrated in a dilution-type experiment similar to that described above for RuBP (Badger \& Lorimer, 1981). In an experiment which is representative of our deactivation studies conducted at $2^{\circ} \mathrm{C}$, we found that two other positive effectors, inorganic phosphate and FBP, and a negative effector, ribose 5-P, exerted similar stabilizing effects on the active enzyme (Figure 1). The pseudo-first-order rate constant for deactivation was decreased by factors of 6,15 , and 200 by $1 \mathrm{mM}$ ribose $5-\mathrm{P}, 10 \mathrm{mM}$ phosphate, and $1 \mathrm{mM}$ $\mathrm{FBP}$, respectively. In the presence of $0.1 \mathrm{mM}$ 6-P-gluconate, 

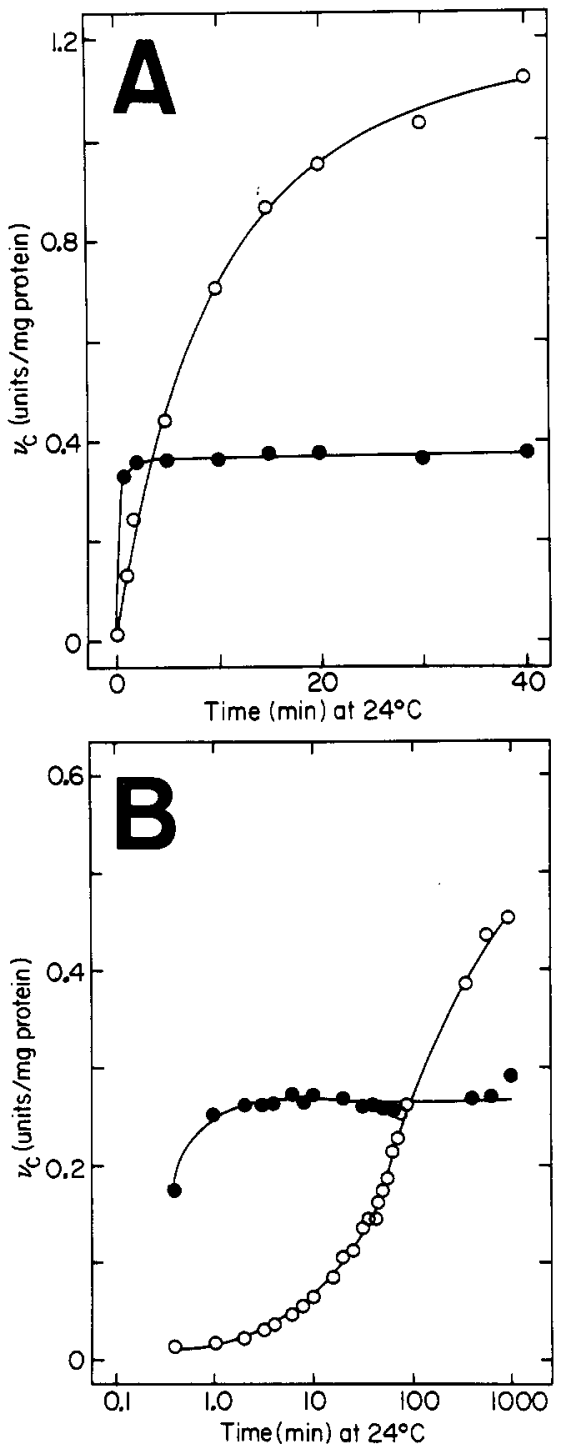

FIGURE 2: Inhibition of the rate of RuBPCase activation by positive effectors. (A) Activation of ryegrass RuBPCase in the presence and absence of 6-P-gluconate. A solution containing $1 \mu \mathrm{mol}$ of 6-Pgluconate was added to $1.4 \mathrm{mg}$ of protein in buffer $\mathrm{A}$ and air levels of $\mathrm{CO}_{2}, \mathrm{pH} 8.0$ at $24^{\circ} \mathrm{C}$, bringing the volume to $0.6 \mathrm{~mL}$. After 2 min of equilibration, $100 \mu \mathrm{L}$ of a solution containing $5 \mu \mathrm{mol}$ of $\mathrm{MgCl}_{2}$ in buffer $\mathrm{A}$ at $\mathrm{pH} 8.0$ was added. Aliquots $(50 \mu \mathrm{L})$ were removed at time intervals to measure RuBP carboxylase activity $\left(\nu_{c}\right)$. Samples incubated with 6-P-gluconate $(O)$ are compared to controls $(\bullet)$ in which 6-P-gluconate was omitted. (B) FBP inhibition of the rate of spinach RuBPCase activation. RuBPCase $(2.65 \mathrm{mg})$ in buffer $A$ and air levels of $\mathrm{CO}_{2}, \mathrm{pH} 7.7$ and $24^{\circ} \mathrm{C}$, was added to a solution containing $0.6 \mu \mathrm{mol}$ of FBP, bringing the volume to $0.50 \mathrm{~mL}$. After $1 \mathrm{~min}$ of equilibration, $50 \mu \mathrm{L}$ of a solution containing $0.1 \mathrm{M} \mathrm{MgCl}_{2}$ in buffer $\mathrm{A}$ at $\mathrm{pH} 7.7$ was added. Aliquots $(10 \mu \mathrm{L})$ were removed at intervals after $\mathrm{Mg}^{2+}$ addition to measure RuBPCase activity $\left(\nu_{c}\right)$. Samples preincubated with FBP $(0)$ are compared to controls $(\bullet)$ in which FBP was omitted. Preincubations were at $24^{\circ} \mathrm{C}$.

no loss of enzyme activity occurred within $25 \mathrm{~min}$. Inhibition of the rate of deactivation was dependent on the concentration of effector. For example, when the concentration of phosphate in the $\mathrm{CO}_{2} / \mathrm{Mg}^{2+}$-free dilution medium was increased from 0.5 to $20 \mathrm{mM}$, inhibition of the deactivation rate increased from $73 \%$ to $93 \%$ (data not shown). Since the rate of deactivation can be inhibited by more than $99 \%$ in the presence of FBP or 6-P-gluconate, it is probable that the effector-bound, active enzyme is incapable of exchanging activator $\mathrm{CO}_{2}$ and $\mathrm{Mg}^{2+}$.

In contrast to a previous study (Badger \& Lorimer, 1981), 6-P-gluconate, other sugar phosphates, and inorganic phos-

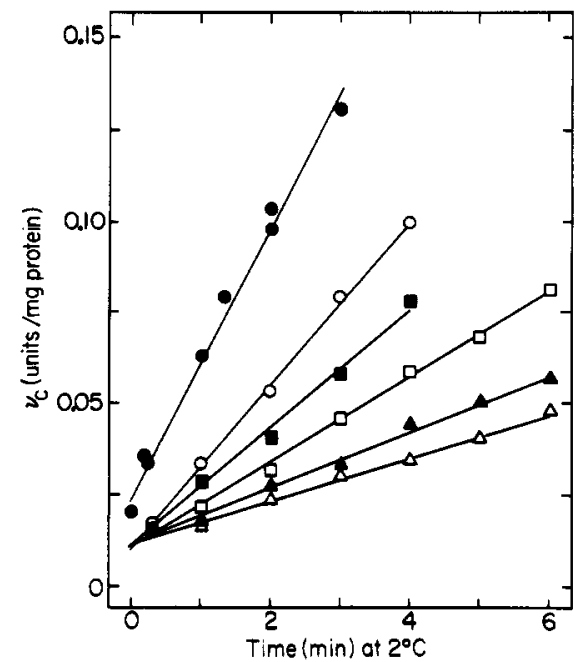

FIGURE 3: Phosphate inhibition of the rate of spinach RuBPCase activation. Activation rates were measured at $2{ }^{\circ} \mathrm{C}$. RuBPCase $(0.60$ mg of protein) was added to varying concentrations of phosphate in buffer $\mathrm{A}$ and air levels of $\mathrm{CO}_{2}$, at $\mathrm{pH} 8.0$, bringing the volume to 0.45 $\mathrm{mL}$. After $1 \mathrm{~min}$ of incubation, $50 \mu \mathrm{L}$ of $0.1 \mathrm{M} \mathrm{MgCl}_{2}$ in buffer $\mathrm{A}$ at $\mathrm{pH} 8.0$ was added. At time intervals after the $\mathrm{MgCl}_{2}$ addition, 25- $\mu \mathrm{L}$ aliquots were removed to measure RuBPCase activity $\left(\nu_{\mathrm{c}}\right)$. Final phosphate concentrations were $0(\bullet), 1.0(0), 2.0(\mathbb{\square}), 5.0(\square), 10.0$ $(\Delta)$, and $20.0 \mathrm{mM}(\Delta)$.

phate were found to inhibit the rate of RuBPCase activation by $\mathrm{CO}_{2}$ and $\mathrm{Mg}^{2+}$. Stabilization of the inactive enzyme form by 6-P-gluconate was demonstrated by comparing the time courses for activation of inactive enzyme that had been preincubated in the absence or presence of this effector (Figure 2A). During the first $2 \mathrm{~min}$ at $24^{\circ} \mathrm{C}$, activation was decreased in the presence of $1.4 \mathrm{mM}$ 6-P-gluconate. Eventually, a 2-fold higher level of RuBPCase activity was attained by the enzyme preincubated with this ligand. A much greater inhibition of the activation rate was observed with FBP. The initial rate of activation was inhibited by more than $98 \%$ when inactive enzyme was preincubated with $1.1 \mathrm{mM}$ FBP (Figure 2B). Enzyme preincubated with this positive effector had not reached an equilibrium activation state even after $16 \mathrm{~h}$ of incubation at $24^{\circ} \mathrm{C}$. The apparent discrepancy between the observed inhibition of the activation rate by positive effectors shown in Figure 2 and the lack of such an effect reported previously (Badger \& Lorimer, 1981) can be explained by the 10 -fold higher concentrations of effectors used in our study. As in the deactivation experiments, inhibition of the activation rate was dependent on the concentration of effector present in the preincubation mixture. For example, in an experiment which is representative of our activation studies conducted at $2{ }^{\circ} \mathrm{C}$, the initial rate of activation was inhibited by $39-84 \%$ when the concentration of inorganic phosphate in the activation medium was increased from 1.0 to $20 \mathrm{mM}$ (Figure 3 ). From the concentration dependence of phosphate inhibition and the nearly complete inhibition of the initial activation rate $(>98 \%)$ observed with $1.1 \mathrm{mM}$ FBP (Figure 2B), it is probable that the effector-bound, inactive enzyme is incapable of $\mathrm{CO}_{2} / \mathrm{Mg}^{2+}$ activation.

Other sugar phosphates induced qualitatively similar effects to those described above. The extent of activation at $\mathrm{pH} 8.0$ and $2{ }^{\circ} \mathrm{C}$, measured $1 \mathrm{~min}$ after the addition of $10 \mathrm{mM} \mathrm{MgCl}$, was decreased in the presence of $1 \mathrm{mM}$ glycolate 2-P, $1 \mathrm{mM}$ fructose 6-P, and $10 \mathrm{mM}$ glycerate 3-P, but when given $5 \mathrm{~h}$ of preincubation after the addition of $\mathrm{Mg}^{2+}$ to approach equilibrium, the amount of active enzyme was either the same (fructose 6-P) or enhanced (glycolate 2-P, glycerate 3-P) relative to the control. 

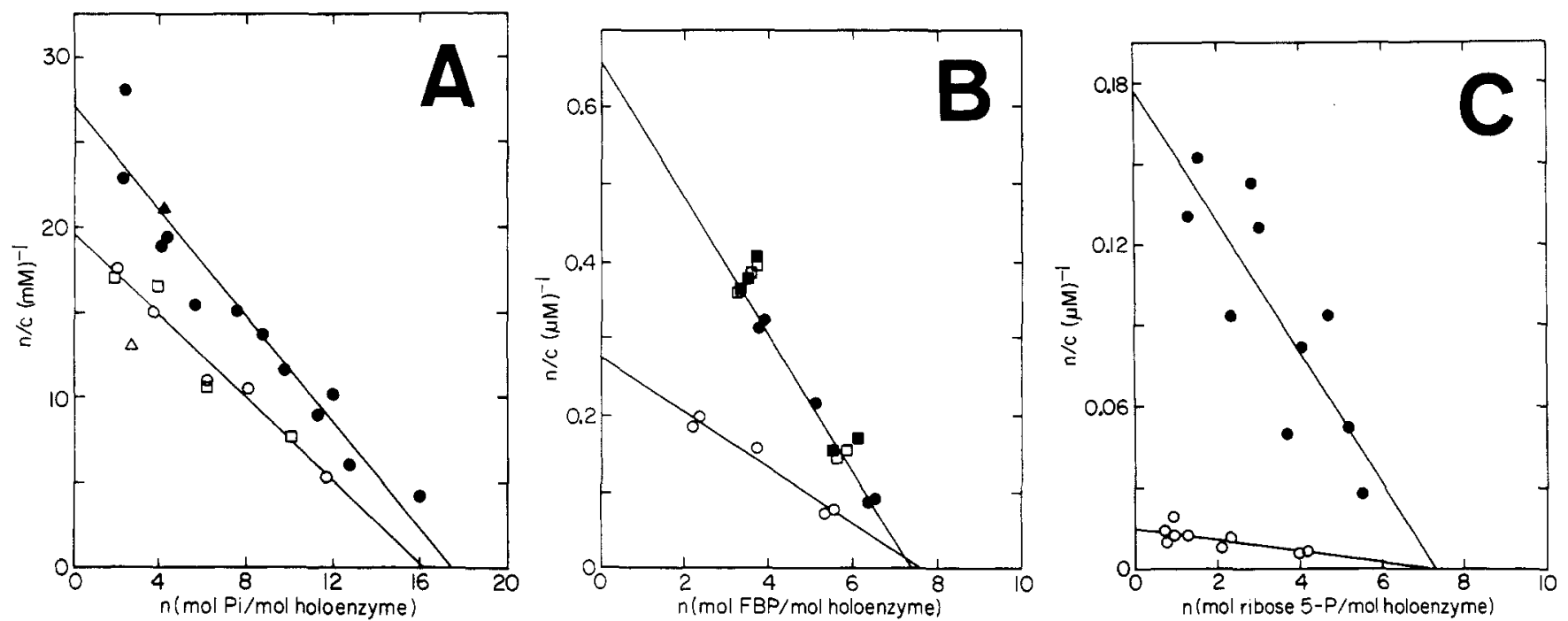

FIGURE 4: Binding of positive and negative effectors by active and inactive forms of spinach RuBPCase. (A) Scatchard plot of [ $\left.{ }^{32} \mathrm{P}\right]$ phosphate binding by active and inactive enzymes. Binding data shown as circles and squares were obtained by using the rate of dialysis method at 4 ${ }^{\circ} \mathrm{C}$. Phosphate additions were made to $1-\mathrm{mL}$ incubations of spinach RuBPCase (38 mg, $67.9 \mathrm{nmol}$ of holoenzyme) in buffer A, pH 8.0 . Inactive enyme (@) contained no metal activator. Active enzyme incubations contained $10 \mathrm{mM} \mathrm{MgCl}_{2}$ and $20 \mathrm{mM} \mathrm{NaHCO}$ ( $\square$ ). Incubations of partially active enzyme $(\sim 30 \%$ active $)$ contained $10 \mathrm{mM} \mathrm{MgCl}$ and air levels of $\mathrm{CO}_{2}(0) . n=\mathrm{mol}$ of phosphate bound/mol of holoenzyme; $c=\mathrm{mM}$ concentration of free phosphate. Phosphate binding data obtained by using equilibrium gel filtration are plotted as open and closed triangles for the active and inactive enzymes, respectively. Enzyme $\left(54 \mu \mathrm{M}\right.$ holoenzyme) was incubated for $15 \mathrm{~min}$ at $4{ }^{\circ} \mathrm{C}$ in buffer $\mathrm{A}$, pH 8.0 , and $200 \mu \mathrm{M}\left[{ }^{32} \mathrm{P}\right]$ phosphate $(314 \mathrm{cpm} / \mathrm{nmol})$ before gel filtration on a column equilibrated with incubation medium. The active enzyme incubation buffer included $10 \mathrm{mM} \mathrm{MgCl}$ and $20 \mathrm{mM} \mathrm{NaHCO}_{3}$. (B) Scatchard plot of FBP binding by active (O) and inactive (๑) spinach RuBPCase. Binding data were obtained at $24{ }^{\circ} \mathrm{C}$ by using the gel filtration method and ${ }^{14} \mathrm{C}$-labeled FBP. Protein $(14-26 \mu \mathrm{M}$ holoenzyme was incubated $15 \mathrm{~min}$ in buffer $\mathrm{A}, \mathrm{pH} 7.7$, and variable concentrations of $\left[{ }^{14} \mathrm{C}\right] \mathrm{FBP}$ before gel filtration. The active enzyme buffer included $10 \mathrm{mM} \mathrm{MgCl}$ and $10 \mathrm{mM} \mathrm{NaHCO}$. FBP concentrations in the incubation and column buffers were 12, 24, and $72 \mu \mathrm{M}$. $n=\mathrm{mol}$ of FBP bound / mol of holoenzyme; $c=\mu \mathrm{M}$ concentration of free FBP. Control experiments were conducted at 9 and $37 \mu \mathrm{M}$ FBP with the following modifications: FBP binding by the inactive enzyme $(\boldsymbol{D})$ was studied in the presence of $1 \mathrm{mM} \mathrm{MgCl}$ under $\mathrm{CO}_{2}$-free conditions, and $\mathrm{FBP}$ binding by the partially active enzyme ( $\square$ ) was studied in the presence of $1 \mathrm{mM} \mathrm{MgCl}$ and $10 \mathrm{mM} \mathrm{NaHCO}$. (C) Scatchard plot of ribose 5-P binding by active (O) and inactive ( $(\bullet)$ spinach RuBPCase. Binding data were obtained at $24^{\circ} \mathrm{C}$ by using $\left[{ }^{14} \mathrm{C}\right]$ ribose $5-\mathrm{P}$ and equilibrium gel filtration. Protein $\left(27-43 \mu \mathrm{M}\right.$ holoenzyme) was incubated $15 \mathrm{~min}$ in buffer $\mathrm{A}, \mathrm{pH} 7.7$, and variable concentrations of $\left[{ }^{14} \mathrm{C}\right]$ ribose $5-\mathrm{P}$ before gel filtration. The active enzyme buffer included $10 \mathrm{mM} \mathrm{MgCl}$ and $10 \mathrm{mM} \mathrm{NaHCO}$. Ribose 5-P concentrations were $10,20,25,50,75$, $100,200,300$, and $600 \mu \mathrm{M} . \quad n=\mathrm{mol}$ of ribose 5-P bound $/ \mathrm{mol}$ of holoenzyme; $c=\mu \mathrm{M}$ concentration of free ribose 5-P.

Existence of Negative Effectors. The protocol routinely used for measuring the effect of sugar phosphates on the activation state of RuBPCase is to preincubate the inactive enzyme with the effector and suboptimal concentrations of $\mathrm{CO}_{2}$ and $\mathrm{Mg}^{2+}$ for 10-30 min prior to assaying for enzyme activity (Badger \& Lorimer, 1981; Hatch \& Jensen, 1980). The very slow rate of activation in the presence of certain positive effectors suggested the possibility that the putative negative effectors had been identified from a preequilibrium condition and that, given sufficient time to reach equilibrium, these compounds would not cause a decrease in enzyme activity. For example, the positive effector, FBP, at a concentration of $1.1 \mathrm{mM}$, would be characterized as a negative effector if the preincubation period was less than $100 \mathrm{~min}$ at 24 ${ }^{\circ} \mathrm{C}$ (Figure 2B).

In order to test for equilibrium, enzyme was activated at a suboptimal concentration of $\mathrm{CO}_{2}$ and $10 \mathrm{mM} \mathrm{Mg}^{2+}$ either before or after the addition of a putative negative effector. If the time of incubation was sufficient to reach equilibrium, the order of addition should have no effect on enzyme activity. The results of such an experiment using a 40-min preincubation period at $24{ }^{\circ} \mathrm{C}$ indicate that this was sufficient time for the enzyme to reach equilibrium in the presence of ribose 5-P, but not in the presence of fructose 6-P or pyrophosphate (Table I). Ribose 5-P was confirmed (Chollet \& Anderson, 1976; Hatch \& Jensen, 1980) to be a negative effector. Fructose 6-P would exert little or no effect on the activation state at equilibrium, while pyrophosphate would be a positive effector.

Binding of Phosphorylated Effectors by Active and Inactive
Enzyme Forms. It has been proposed that the positive effectors shift the equilibrium of eq 1 toward the activated enzyme species because of a greater affinity for the active enzyme form than for the inactive form and that the opposite would hold for the negative effectors (Badger \& Lorimer, 1981; McCurry et al., 1981). We examined this hypothesis with the positive effectors inorganic phosphate, FBP, and glycerate 3-P and the negative effector ribose 5-P. At suboptimal concentrations of activator $\mathrm{CO}_{2}$ and $\mathrm{Mg}^{2+}$, each of these positive effectors increased the amount of active enzyme at equilibrium by a factor of 3 or more. Ribose 5-P decreased the amount of active enzyme by about $25 \%$ (Table I). Thus, the differential binding hypothesis predicts that the active enzyme should have at least a 3-fold greater affinity for inorganic phosphate, FBP, and glycerate $3-\mathrm{P}$ and about a $25 \%$ decreased affinity for ribose 5-P in comparison to the inactive enzyme.

Phosphate binding studies indicated that there are 16 phosphate binding sites per enzyme molecule ( 2 sites per 70 $\mathrm{kDa}$ protomer) for both active and inactive enzyme forms (Figure 4A). The estimated dissociation constants for the inactive and active enzymes were 650 and $830 \mu \mathrm{M}$ phosphate, respectively. The greater apparent affinity for phosphate displayed by the inactive enzyme form was confirmed by equilibrium gel filtration at $200 \mu \mathrm{M}$ phosphate, and these data are plotted with those from the dialysis method (Figure 4A). It is estimated that about $26 \%$ of the phosphate present in the active enzyme incubations was complexed with $\mathrm{Mg}^{2+}$ (see Methods). If it is assumed that the $\mathrm{Mg}^{2+}$-phosphate complex does not bind to the enzyme, as has been observed for the 
Table I: Examination of Effectors of RuBPCase

Activation at Equilibrium

\begin{tabular}{ccc}
\hline & $\begin{array}{c}\text { preincubation treatment } \\
\text { effector (mM) } \\
\text { for RuBPCase activity } \\
\text { (\% of control) }\end{array}$ \\
\cline { 2 - 3 } none (control) & A & B \\
ribose 5-P (0.1) & 100 & 100 \\
ribose 5-P (0.5) & 82 & 83 \\
ribose 5-P (2.0) & 79 & 74 \\
fructose 6-P (0.1) & 74 & 69 \\
fructose 6-P (0.5) & 92 & 113 \\
fructose 6-P (2.0) & 85 & 116 \\
pyrophosphate (0.1) & 74 & 118 \\
pyrophosphate (0.5) & 145 & 163 \\
pyrophosphate (2.0) & 149 & 159 \\
\hline
\end{tabular}

${ }^{a}$ In (A), $0.4 \mathrm{~mL}$ of spinach RuBPCase $(0.63 \mathrm{mg} / \mathrm{mL})$ in buffer A, $\mathrm{pH} 7.7$, containing air levels of $\mathrm{CO}_{2}$ was added to $50 \mu \mathrm{L}$ of effector at $24^{\circ} \mathrm{C}$. After $1 \mathrm{~min}$ of preincubation, $50 \mu \mathrm{L}$ of $0.1 \mathrm{M}$ $\mathrm{MgCl}_{2}$ in buffer A, pH 7.7, was added. Following 40 min of incubation at $24{ }^{\circ} \mathrm{C}, 25-\mu \mathrm{L}$ aliquots were removed to determine RuBPCase activity. In (B) the order of addition was reversed. RuBPCase was preincubated for $10 \mathrm{~min}$ with $\mathrm{Mg}^{2+}$ prior to the addition of effector. RuBPCase activity was determined $40 \mathrm{~min}$ after the addition of effector. Final concentrations of effector are listed. Control RuBPCase activity was $0.205 \mathrm{unit} / \mathrm{mg}$ of protein.

$\mathrm{Mg}^{2+}-\mathrm{RuBP}$ complex (Christeller, 1981), the $K_{\mathrm{D}}$ (phosphate) measured for the active enzyme is decreased by $26 \%$. With this correction, the active enzyme $K_{\mathrm{D}}$ (phosphate) approximately equals that of the inactive enzyme. This correction appears valid, based on the observation that partially active enzyme ( $\sim 30 \%$ active), in the presence of $10 \mathrm{mM} \mathrm{MgCl}$ and air levels of $\mathrm{CO}_{2}$ at $4{ }^{\circ} \mathrm{C}$, bound phosphate similarly to the fully active enzyme incubated with $10 \mathrm{mM} \mathrm{MgCl}$ and $20 \mathrm{mM}$ $\mathrm{NaHCO}_{3}$ (Figure 4A). Thus, the active and inactive enzyme forms appear to have the same affinity for phosphate $\left(K_{\mathrm{D}}=\right.$ $650 \mu \mathrm{M})$.

As was found for phosphate, FBP bound with greater apparent affinity to the inactive enzyme form $\left(K_{\mathrm{D}}=11 \mu \mathrm{M}\right)$ than to the active form $\left(K_{\mathrm{D}}=28 \mu \mathrm{M}\right.$; Figure $\left.4 \mathrm{~B}\right)$. However, as indicated under Methods, it is estimated that about $80 \%$ of the FBP was complexed with $\mathrm{Mg}^{2+}$ in the active enzyme incubations containing $10 \mathrm{mM} \mathrm{MgCl}_{2}$. For this reason, control experiments were conducted with the active and inactive enzymes in the presence of $1 \mathrm{mM} \mathrm{MgCl}$ where it was estimated that less than $18 \%$ of the FBP was complexed with $\mathrm{Mg}^{2+}$. FBP binding data obtained for the partially active enzyme in $1 \mathrm{mM}$ $\mathrm{MgCl}_{2}$ and $10 \mathrm{mM} \mathrm{NaHCO}{ }_{3}(\sim 70 \%$ active under these conditions) were nearly identical with those for the inactive enzyme in the presence of $1 \mathrm{mM} \mathrm{MgCl}{ }_{2}$ under $\mathrm{CO}_{2}$-free conditions (Figure 4B). It is concluded that the active and inactive enzyme forms have the same affinity for FBP $\left(K_{\mathrm{D}}=\right.$ $11 \mu \mathrm{M})$ and that both enzyme forms have one FBP binding site per enzyme protomer. When $100 \mu \mathrm{M}$ RuBP was added to the column buffer containing $10 \mu \mathrm{M}$ FBP, the inactive enzyme was prevented from binding FBP. Similarly, when $100 \mu \mathrm{M}$ CABP was added to the column buffer containing $10 \mu \mathrm{M}$ FBP, the active enzyme form was prevented from binding FBP. This exclusion of FBP by RuBP and CABP is consistent with the proposal (Badger \& Lorimer, 1981; McCurry et al., 1981) that the effectors bind at the RuBP site within the large catalytic subunit.

The binding of a third positive effector, glycerate 3-P, was studied at $24{ }^{\circ} \mathrm{C}$ with ${ }^{14} \mathrm{C}$-labeled glycerate $3-\mathrm{P}$, equilibrium gel filtration, and spinach RuBPCase. In order to avoid a significant amount of $\mathrm{Mg}^{2+}$ complexing, the active enzyme
Table II: Comparison of the Rates of Spinach RuBPCase Activation and Deactivation in the Presence of Effectors

\begin{tabular}{lccr}
\hline effector (mM) & $\begin{array}{c}\text { activation } \\
\text { rate }^{a}(\mathrm{~A})\end{array}$ & $\begin{array}{c}\text { deactivation } \\
\text { rate }^{b}(\mathrm{~B})\end{array}$ & $\mathrm{A} / \mathrm{B}$ \\
\hline control & 1.0 & 1.0 & 1.0 \\
ribose 5-P (1.0) & 0.38 & 0.16 & 2.4 \\
phosphate $(1.0)$ & 0.61 & 0.17 & 3.6 \\
FBP $(0.12)$ & 0.37 & 0.007 & 53 \\
6-P-gluconate $(0.1)$ & 0.68 & $0.0049^{c}$ & 139 \\
\hline${ }^{a}$ Activation rates were measured at $2^{\circ} \mathrm{C}$ as described for Figure \\
3. Values are normalized to the control rate, which was 0.037 \\
unit (mg of protein) ${ }^{-1}$ min ${ }^{-1}$. $b$ Deactivation rates were measured \\
at $2{ }^{\circ} \mathrm{C}$ as described for Figure 1. Values are normalized to the \\
control $K_{\text {obsd }}$, which was 0.623 min $^{-1}$. c The deactivation rate \\
was measured at $24{ }^{\circ} \mathrm{C}$. The control rate was 5.23 min $^{-1}$. \\
\hline
\end{tabular}

incubations contained $1 \mathrm{mM} \mathrm{MgCl}$ and $10 \mathrm{mM} \mathrm{NaHCO}_{3}$ in buffer $\mathrm{A}$. Inactive enzyme was studied in buffer $\mathrm{A}$ without $\mathrm{Mg}^{2+}$. The results of the binding study (data not shown) indicated that glycerate 3-P bound to the inactive enzyme $\left(K_{\mathrm{D}}\right.$ $=25 \mu \mathrm{M})$ with greater affinity than to the active enzyme $\left(K_{\mathrm{D}}\right.$ $=76 \mu \mathrm{M})$. These values are considerably lower than the $K_{\mathrm{D}}$ of $1.2 \mathrm{mM}$ determined for glycerate 3-P binding to the active enzyme in the presence of $20 \mathrm{mM} \mathrm{MgCl}_{2}$ (Badger \& Lorimer, 1981). The active and inactive enzyme forms possessed one glycerate 3-P binding site per enzyme protomer.

Binding data for the negative effector ribose 5-P indicated that the ligand bound to the inactive enzyme $\left(K_{\mathrm{D}}=42 \mu \mathrm{M}\right)$ with much greater affinity than to the active enzyme $\left(K_{\mathrm{D}}=\right.$ $480 \mu \mathrm{M}$; Figure $4 \mathrm{C}$ ). Both the active and inactive enzyme forms possessed one ribose 5-P binding site per $70-\mathrm{kDa}$ protomer. Complex formation of ribose 5-P with $\mathrm{Mg}^{2+}$ was estimated to decrease the free ribose 5-P concentration by $26 \%$ in the active enzyme incubations with contained $10 \mathrm{mM}$ $\mathrm{MgCl}_{2}$. A control experiment was conducted with inactive enzyme under $\mathrm{CO}_{2}$-free conditions to verify the magnitude of the $\mathrm{Mg}^{2+}$ effect. At $50 \mu \mathrm{M}$ ribose $5-\mathrm{P}, 10 \mathrm{mM} \mathrm{MgCl}_{2}$ inhibited the amount of ribose 5-P bound to the inactive enzyme by $30 \%$ in agreement with the estimate. However, in another experiment at $75 \mu \mathrm{M}$ ligand, ribose $5-\mathrm{P}$ binding by the inactive enzyme was inhibited by $27 \%$ in the presence of $20 \mathrm{mM} \mathrm{NaCl}$. The latter result suggests that not all of inhibition observed with $\mathrm{MgCl}_{2}$ is attributable to the formation of $\mathrm{Mg}^{2+}$-ligand complexes. After correcting for $30 \%$ inhibition by $10 \mathrm{mM}$ $\mathrm{MgCl}_{2}$, the affinity of the active enzyme for ribose 5-P is still less than that of the inactive enzyme by a factor of 8 .

Comparison of Effector Stabilization of Active and Inactive Enzyme Forms. An alternative mechanism to the differential binding hypothesis of Badger \& Lorimer (1981) and McCurry et al. (1981) is that positive effectors promote RuBPCase activation by stabilization of the active enzyme form to a greater extent than the inactive enzyme form. In this view, the release of activator $\mathrm{CO}_{2}$ and $\mathrm{Mg}^{2+}$ from the active enzyme form is impeded more by effectors than is the binding of activator $\mathrm{CO}_{2}$ and $\mathrm{Mg}^{2+}$ to the inactive enzyme. Consistent with this hypothesis, phosphorylated effectors inhibited the activation rate less than the rate of deactivation (Table II). The ratio of the activation to deactivation rates was increased in the presence of the phosphorylated effectors, including ribose 5-P, which has been characterized as a negative effector (Table I; Chollet \& Anderson, 1976; Hatch \& Jensen, 1980). The ratio favored the active enzyme less in the presence of ribose 5-P, however, than in the presence of the positive effectors, inorganic phosphate, FBP, and 6-P-gluconate.

Inhibition of the rate of activation by effectors was studied at several activator $\mathrm{CO}_{2}$ concentrations because the initial rate 


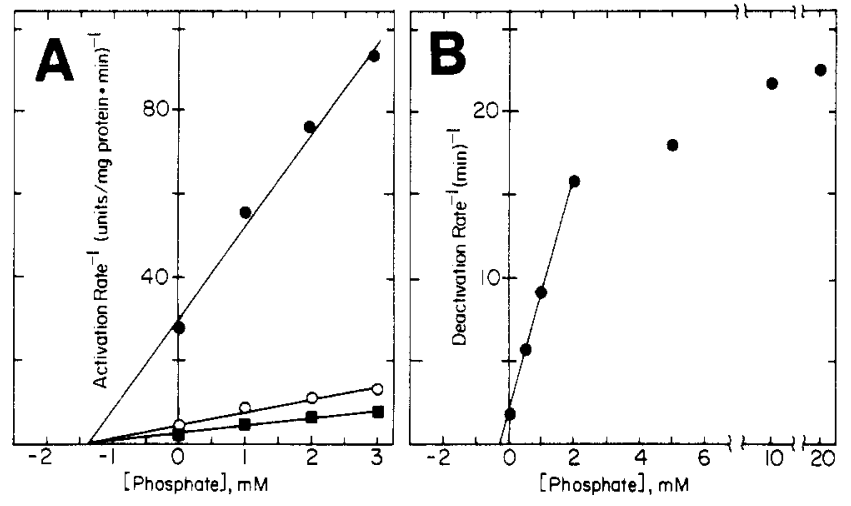

FIGURE 5: Dixon plots demonstrating phosphate inhibition of the activation and deactivation rates of spinach RuBPCase. (A) Activation rates were measured at $2^{\circ} \mathrm{C}$ at varying concentrations of phosphate and three fixed concentrations of activator $\mathrm{CO}_{2}$. RuBPCase $(0.60$ $\mathrm{mg}$ of protein) was incubated $1 \mathrm{~min}$ in buffer $\mathrm{A}$ containing varying concentrations of phosphate and air levels of $\mathrm{CO}_{2}$, at $\mathrm{pH} 8.0$, in a volume of $0.45 \mathrm{~mL}$. Activation was initiated by adding $50 \mu \mathrm{L}$ of buffer A containing $0.1 \mathrm{M} \mathrm{MgCl}$ and the appropriate concentration of $\mathrm{NaHCO}_{3}$. At time intervals after initiating activation, $25-\mu \mathrm{L}$ aliquots were removed to measure RuBPCase activity. The initial rate of activation was determined from the time courses, and the reciprocals of these values are plotted vs. the phosphate concentration in the complete activation mixture. Air levels of $\mathrm{CO}_{2}(\sim 10 \mu \mathrm{M} \mathrm{CO})_{2}(\bullet)$, $60 \mu \mathrm{M} \mathrm{CO}_{2}(\mathrm{O})$, and $105 \mu \mathrm{M} \mathrm{CO}_{2}(\boldsymbol{D})$. (B) Deactivation rates were measured at $2^{\circ} \mathrm{C}$ at varying concentrations of phosphate. The protocol in the legend to Figure 1 was used with these changes: active enzyme was $8.5 \mathrm{mg} / \mathrm{mL}$ before dilution, and $25-\mu \mathrm{L}$ aliquots of the deactivation mixture were assayed for RuBPCase activity. The reciprocals of the deactivation rates $\left(K_{\text {obsd }}\right)$ are plotted vs. the phosphate concentration in the deactivation mixture.

of RuBPCase activation is limited by the concentration of $\mathrm{CO}_{2}$ and independent of the $\mathrm{Mg}^{2+}$ concentration (Lorimer et al., 1976). A Dixon plot of phosphate inhibition at three fixed $\mathrm{CO}_{2}$ concentrations demonstrated that inhibition by phosphate was noncompetitive with respect to activator $\mathrm{CO}_{2}$ (Figure 5A). From experiments at two fixed concentrations of $\mathrm{CO}_{2}$, inhibition of the activation rate by FBP, 6-P-gluconate, and ribose 5-P also appeared to be noncompetitive with respect to activator $\mathrm{CO}_{2}$. Dixon plots were linear at low inhibition levels but became hyperbolic at higher levels of inhibition (>85\%). $K_{\mathrm{i}}$ values estimated from the linear portion of the Dixon plots are given in Table III. The $K_{\mathrm{i}}$ values for inhibition of the activation rate by inorganic phosphate, FBP, and 6-P-gluconate were 2-3 times as large as their respective dissociation constants. The $K_{\mathrm{i}}$ value for ribose 5-P inhibition of the activation rate was nearly an order of magnitude greater than the binding constant with inactive enzyme.

Dixon plots demonstrating inhibition of the deactivation rate by inorganic phosphate (Figure 5B), FBP, 6-P-gluconate, and ribose 5-P were also linear until very high levels of inhibition were reached. $K_{\mathrm{i}}$ values were estimated from the linear portion of the plots and are given in Table III. The $K_{\mathrm{i}}$ values for all four effectors were considerably lower than their respective dissociation constants with the active enzyme. Moreover, the $K_{\mathrm{i}}$ values for the deactivation rate were smaller than the $K_{\mathrm{i}}$ values for the activation rate by factors ranging from 2 to 670 , once again demonstrating greater inhibition of deactivation than of activation by effectors (also see Table II).

\section{Discussion}

This study indicates that several phosphorylated effectors of RuBP carboxylase bind to inactive enzyme and enzyme which is activated with respect to $\mathrm{CO}_{2}$ and $\mathrm{Mg}^{2+}$. These phosphorylated compounds mimic the effects observed with the substrate RuBP by altering the kinetics of $\mathrm{CO}_{2} / \mathrm{Mg}^{2+}$
Table III: Comparison of Effector Dissociation Constants and Inhibition Constants for the Rates of Activation and Deactivation of Spinach RuBPCase

\begin{tabular}{lccccc}
\hline \multicolumn{1}{c}{ effector } & $\begin{array}{c}K_{\mathrm{i}}{ }^{a} \\
\text { activation } \\
(\mathrm{A})(\mu \mathrm{M})\end{array}$ & $\begin{array}{c}\left.K_{\mathrm{D}}\right)^{b} \\
(\mu \mathrm{M})\end{array}$ & $\begin{array}{c}K_{\mathrm{i}}{ }^{c} \\
\text { deactivation } \\
(\mathrm{B})(\mu \mathrm{M})\end{array}$ & $\begin{array}{c}\left(K_{\mathrm{D}}\right)^{d} \\
(\mu \mathrm{M})\end{array}$ & $\mathrm{A} / \mathrm{B}$ \\
\hline phosphate & 1600 & $(650)$ & 260 & $(650)$ & 6.2 \\
FBP & 33 & $(11)$ & 1.3 & $(11)$ & 25 \\
6-P-gluconate & 140 & $(37)$ & 0.21 & $(37)$ & 670 \\
ribose 5-P & 390 & $(42)$ & 210 & $(480)$ & 1.9 \\
\hline
\end{tabular}

${ }^{a}$ The initial rates of activation at $2{ }^{\circ} \mathrm{C}$ in the presence of varying concentrations of phosphate were determined from the slopes of the lines in Figure 3 . The activation rates in the presence of varying concentrations of FBP $(0,24,36,60,120,240,360$, and $600 \mu \mathrm{M}), 6$-P-gluconate $(0,20,50,100,200$, and $400 \mu \mathrm{M})$, and ribose 5-P $(0,0.5,1,2,4$, and $6 \mathrm{mM})$ were determined from time courses at $2{ }^{\circ} \mathrm{C}$ by using the protocol described for phosphate in the legend to Figure 3 . $K_{\mathrm{i}}$ values were estimated from the linear portions of the respective Dixon plots (also see Figure $5 \mathrm{~A}$ for phosphate inhibition). ${ }^{b} K_{\mathrm{D}}$ values for phosphate, FBP, and ribose 5-P with inactive enzyme were taken from the text. The binding constant for 6-P-gluconate with inactive enzyme is not available, and the $K_{\mathrm{D}}$ with active enzyme (Badger \& Lorimer, 1981) is used instead. ${ }^{\mathcal{C}}$ The rates of deactivation in the presence of varying concentrations of inorganic phosphate $(0,0.5,1.0,2.0,5.0$, and $20 \mathrm{mM}), \mathrm{FBP}(0,0.2,0.4,0.6,1$, and $2 \mu \mathrm{M}), 6$-P-gluconate $(0$, $0.1,0.2,0.3,0.5$, and $1 \mu \mathrm{M})$, and ribose $5-\mathrm{P}(0,0.25,0.5,1,2,4$, and $6 \mathrm{mM}$ ) were measured at $2{ }^{\circ} \mathrm{C}$ by using the protocol described in the legend to Figure 1 with the exception that the concentration of active enzyme (before 50 -fold dilution) was $8.5 \mathrm{mg} / \mathrm{mL}$. $K_{\mathrm{i}}$ values were estimated from the linear portion of the respective Dixon plots (see Figure 5B for phosphate inhibition). ${ }^{d} K_{\mathrm{D}}$ values for phosphate, FBP, and ribose 5-P with active enzyme were taken from the text. The $K_{\mathrm{D}}$ value for 6 -P-gluconate with active enzyme was taken from another report (Badger \& Lorimer, 1981).

activation described by eq 2 . Both the active and inactive enzymes are stabilized by incubation with the effectors, and this stabilization is accomplished by decreasing the rates of interconversion between active and inactive enzyme forms. When the enzyme is nearly saturated with effector, the rates of activation and deactivation are very slow compared to those observed for enzyme in the absence of effector. This suggests that the effector-bound enzyme is incapable of activator $\mathrm{CO}_{2}$ and $\mathrm{Mg}^{2+}$ exchange and that the residual rates of activation and deactivation observed can be attributed to the small amount of free enzyme in equilibrium with the enzyme bound to effector.

The similarities observed in the enzyme's response to substrate RuBP and to other phosphorylated effectors are consistent with the proposal that effectors influence $\mathrm{CO}_{2} / \mathrm{Mg}^{2+}$ activation through an interaction with the RuBP binding site (Badger \& Lorimer, 1981; McCurry et al., 1981). Effector binding may lead to a change in the protein conformation which confers steric hindrance to the exchange of activator $\mathrm{CO}_{2}$ and $\mathrm{Mg}^{2+}$ molecules. In this sense, the effectors would elicit a response similar to, but less severe than, that observed with the tight-binding inhibitor $\mathrm{CABP}$, which causes the enzyme to bind activator $\mathrm{CO}_{2}$ and $\mathrm{Mg}^{2+}$ in a nearly irreversible fashion (Miziorko, 1979; Lorimer \& Miziorko, 1980). Spectral evidence for effector-induced conformational changes in the inactive and active enzymes has been observed, but not characterized (Trown \& Rabin, 1964; Vater \& Salnikow, 1979).

At equilibrium, the active enzyme form is favored by positive effectors. Two possible mechanisms for this enhancement based on the equilibria of eq 2 are (a) active enzyme has a greater binding affinity than inactive enzyme for positive effectors, or (b) positive effectors preferentially stabilize the active enzyme by inhibiting the exchange of activator $\mathrm{CO}_{2}$ and 
$\mathrm{Mg}^{2+}$ from the active enzyme more than with the inactive enzyme.

The first possibility was considered axiomatic to the mechanism of positive effector-induced activation (Badger \& Lorimer, 1981), but experimental evidence described herein contradicts this supposition. The hypothesis was tested directly in binding studies with the positive effectors inorganic phosphate, FBP, and glycerate 3-P (Figure 4A,B). The results indicated that the inactive enzyme has equal or greater affinity for these ligands than does the active enzyme form. On the basis of preferential binding per se, these phosphates should either have no effect or act as negative effectors.

In addition, we found the results from the deactivation experiments with 6-P-gluconate to be inconsistent with the hypothesis that the active enzyme is stabilized merely by shifting the equilibria of eq 2 toward the effector-bound form of the active enzyme. The concentration of 6-P-gluconate required to inhibit the rate of deactivation by $50 \%$ was found to be $0.21 \mu \mathrm{M}$ (Table III). The preferential binding hypothesis predicts that half of the enzyme should be bound with ligand at $0.21 \mu \mathrm{M}$ 6-P-gluconate. This was not the case, however, because the concentration of enzyme in the experiment was $2.4 \mu \mathrm{M}$ with respect to enzyme protomer, more than an order of magnitude in excess of the total ligand concentration. The mechanism of RuBPCase activation by positive effectors must account for the stabilization of active enzyme by catalytic amounts of 6-P-gluconate.

The alternative mechanism of effector-enhanced activation, preferential stabilization of the active enzyme form, became more evident when the complication of preferential binding was eliminated. In tobacco RuBPCase, the equilibrium activation constants for $\mathrm{CO}_{2}$ and $\mathrm{Mg}^{2+}$ were decreased severalfold in the presence of $0.1 \mathrm{mM} 6-\mathrm{P}$-gluconate (Hatch \& Jensen, 1980). In a related experiment which used the transition-state analogue, $\mathrm{CABP}$, to trap ${ }^{14} \mathrm{C}$-labeled activator $\mathrm{CO}_{2}$ molecules onto the active enzyme (McCurry et al., 1981), it was demonstrated that increasing concentrations of 6-Pgluconate or inorganic phosphate permitted greater amounts of activator $\mathrm{CO}_{2}$ molecules to be trapped. The increases in activator $\mathrm{CO}_{2}$ molecules trapped were matched stoichiometrically by increases in carboxylase activity. Hence, for the positive effector inorganic phosphate, which is known not to shift the equilibrium toward the active enzyme through preferential binding (Figure 4A), it may be concluded that the amount of active enzyme is increased by stabilizing the activator $\mathrm{CO}_{2}$ and $\mathrm{Mg}^{2+}$ molecules on the active enzyme form. At equilibrium, the activated enzyme is favored because this form is stabilized to a greater extent by phosphate than is the inactive form (Tables II and III and Figure 5).

A possible mechanism for differential stabilization of the active and inactive enzyme forms was deduced from the differences between the effector dissociation constants and $K_{\mathrm{i}}$ values for inhibition of the rates of activation and deactivation (Table III). The effector concentrations required for $50 \%$ inhibition of the deactivation rate were much lower than the measured dissociation constants for the effectors. We propose that this apparent increase in affinity for the effector is conferred to the active enzyme by a more rapid rate of effector binding in comparison to the slow rate of $\mathrm{CO}_{2}$ and $\mathrm{Mg}^{2+}$ release during deactivation. It is envisioned that the deactivation process involves a slow relaxation to a condition in which the enzyme is capable of losing activator $\mathrm{CO}_{2}$ and $\mathrm{Mg}^{2+}$ molecules and that effector binding opposes deactivation by causing the active enzyme to assume its most stable configuration. This stable condition persists until the effector is

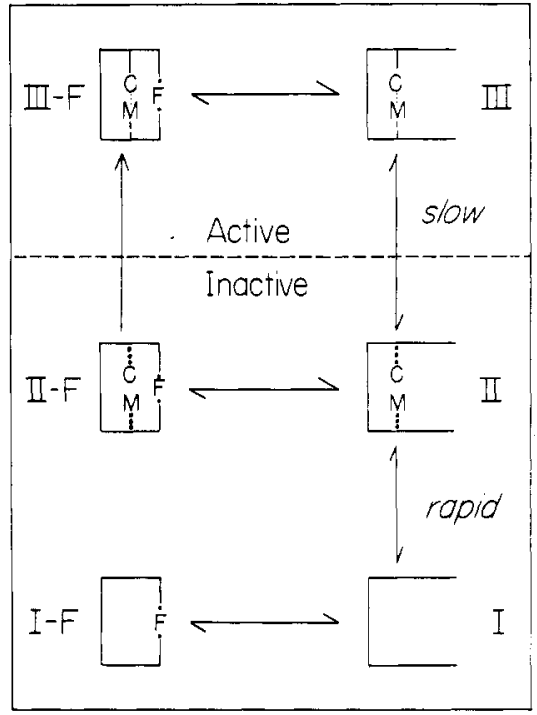

FIGURE 6: Working model for positive effector-induced activation of RuBPCase. $\mathrm{C}, \mathrm{M}$, and $\mathrm{F}$ represent activator $\mathrm{CO}_{2}, \mathrm{Mg}^{2+}$, and effector ligands, respectively. Enzyme species above the horizontal dashed line are considered active, while those below the line are inactive. For simplicity, activator $\mathrm{CO}_{2}$ and $\mathrm{Mg}^{2+}$ are considered to bind simultaneously. The major features of the model are the following: (1) Positive effectors bind with approximately equal affinity to all effector-free enzyme forms. (2) $\mathrm{CO}_{2}$ and $\mathrm{Mg}^{2+}$ bind and release only from effector-free enzyme. (3) The binding of $\mathrm{CO}_{2}$ and $\mathrm{Mg}^{2+}$ is divided into a fast and a slow step. In comparison to the slow interconversion of forms II and III, other transitions are more rapid. (4) Positive effector binding promotes the slow step of $\mathrm{CO}_{2}$ and $\mathrm{Mg}^{2+}$ binding by stabilizing these ligands and preventing their release. See Discussion for further explanation.

released and the slow relaxation of the enzyme is resumed. Rapid effector binding would allow several stabilization events to occur in the time required for a single deactivation event. Hence, a greater concentration of enzyme could be stabilized in the active state than is actually bound to effector.

The $K_{\mathrm{i}}$ values for effector inhibition of the activation rate were larger than the effector dissociation constants (Table III). To account for this observation, the binding of activator $\mathrm{CO}_{2}$ and $\mathrm{Mg}^{2+}$ may be divided into a rapid phase followed by a slow phase. For the activator $\mathrm{CO}_{2}$ molecule this would perhaps involve a rapid positioning within the activator site followed by slow formation of the carbamate. An effector would inhibit the activation rate only when it was bound to the enzyme. Free enzyme would be available for both activator $\mathrm{CO}_{2}$ and $\mathrm{Mg}^{2+}$ binding and effector binding. The ability of activator $\mathrm{CO}_{2}$ and $\mathrm{Mg}^{2+}$ to bind rapidly with the free enzyme would equalize the $K_{\mathrm{i}}$ value for effector inhibition of the activation rate and the effector dissociation constant. However, once activator $\mathrm{CO}_{2}$ and $\mathrm{Mg}^{2+}$ were bound to free enzyme, the binding of an effector molecule would tend to stabilize the active enzyme form, thus reducing the amount of inhibition observed and increasing the measured inhibition constant. Effector inhibition of the activation rate appeared to be noncompetitive with respect to activator $\mathrm{CO}_{2}$ (Figure 5A), so the possibility that the inhibition constants were increased by competition between activator $\mathrm{CO}_{2}$ and effector for free enzyme was rejected.

A working model for positive effector-induced activation is depicted in Figure 6. For simplicity, activator $\mathrm{CO}_{2}$ and $\mathrm{Mg}^{2+}$ molecules are considered to bind simultaneously. The major features of the model are the following: (a) Positive effectors bind with approximately equal affinity to all effector-free enzyme forms (I-III). (b) The effector-bound enzyme forms do not bind or release activator $\mathrm{CO}_{2}$ and $\mathrm{Mg}^{2+}$. (c) The activators $\mathrm{CO}_{2}$ and $\mathrm{Mg}^{2+}$ are positioned within the activator 
site of the enzyme in a rapid step (form II). This is followed by a slow step in which activator $\mathrm{CO}_{2}$ and $\mathrm{Mg}^{2+}$ are rearranged to assume their active configuration within the activator site (form III)-in the case of $\mathrm{CO}_{2}$ this would presumably entail carbamate formation or destruction. The release of activator $\mathrm{CO}_{2}$ and $\mathrm{Mg}^{2+}$ (i.e., deactivation) would occur in a reverse fashion, with the slow step preceding the rapid step. (d) Once activator $\mathrm{CO}_{2}$ and $\mathrm{Mg}^{2+}$ are bound to the enzyme, the binding of an effector induces a more stable configuration. When the release of $\mathrm{CO}_{2}$ and $\mathrm{Mg}^{2+}$ from the enzyme is prevented, the effector would, in essence, catalyze the formation of active enzyme. For this reason, the transition from form II-F to form III-F is thought to occur more rapidly than the transition from form II to form III.

In the absence of preferential effector binding by active or inactive enzyme forms, the ability of a compound to promote activation of RuBPCase at equilibrium (i.e., positive effector) would depend on the relative rate of effector binding and enzyme stabilization (conversion of form II to form III-F) in comparison to the rate of deactivation (conversion of form III to form I). Rapid effector binding and stabilization would allow a greater portion of the activated enzyme population to be stabilized than is actually bound to effector. It is thought that both positive and negative effectors satisfy the above criterion of rapid binding and stabilization of the enzyme. Indeed, although there were striking differences among the phosphorylated effectors examined in their abilities to stabilize the active and inactive enzyme forms, all of the compounds, including the negative effector ribose 5-P, were more effective in preventing deactivation than activation of RuBPCase (Tables II and III). Positive effectors bind with similar affinities to active and inactive enzymes (Figure 4A,B), and their promotion of activation is governed by superior stabilization of the active enzyme form. The positive influence of ribose 5-P in stabilizing the active enzyme is outweighed, however, by the greatly increased affinity of the inactive enzyme form for this ligand (Figure 4C). Thus, the overall response of RuBPCase activation to ribose 5-P and other effectors is determined by the magnitude of these positive and negative properties.

Registry No. RuBPCase, 9027-23-0; $\mathrm{CO}_{2}, 124-38-9 ; \mathrm{Mg}, 7439-$ 95-4; ribose 5-P, 4300-28-1; fructose 6-P, 643-13-0; FBP, 488-69-7; 6-P-gluconate, 921-62-0; 3-phosphoglycerate, 820-11-1; pyrophosphate, 2466-09-3; inorganic phosphate, 14265-44-2; glycolate 2-P, 13147-57-4.

References

Badger, M. R. (1980) Arch. Biochem. Biophys. 201, 247-254. Badger, M. R., \& Lorimer, G. H. (1981) Biochemistry 20, 2219-2225.
Chaberek, S., Jr., Courtney, R. C., \& Martell, A. E. (1953) J. Am. Chem. Soc. 75, 2185-2190.

Chollet, R., \& Anderson, L. L. (1976) Arch. Biochem. Biophys. 176, 344-351.

Christeller, J. T. (1981) Biochem. J. 193, 839-844.

Christeller, J. T., \& Laing, W. A. (1978) Biochem. J. 173, 467-473.

Chu, D. K., \& Bassham, J. A. (1975) Plant Physiol. 55, 720-726.

Colowick, S. P., \& Womack, F. C. (1969) J. Biol. Chem. 244, 774-777.

Frey, C. M., \& Stuehr, J. E. (1972) J. Am. Chem. Soc. 94, 8898-8904.

Hall, N. P., McCurry, S. D., \& Tolbert, N. E. (1981) Plant Physiol. 67, 1220-1223.

Hatch, A. L., \& Jensen, R. G. (1980) Arch. Biochem. Biophys. $205,587-594$.

Horecker, B. L., Hurwitz, J., \& Weissbach, A. (1956) J. Biol. Chem. 218, 785-793.

Hummel, J. P., \& Dreyer, W. J. (1962) Biochim. Biophys. Acta 63, 530-532.

Jordan, D. B., \& Ogren, W. L. (1981a) Plant Physiol. 67, 237-245.

Jordan, D. B., \& Ogren, W. L. (1981b) Nature (London) 291, 513-515.

Laing, W. A., \& Christeller, J. T. (1976) Biochem. J. 159 , 563-570.

Larsson-Răznikiewicz, M. (1972) Eur. J. Biochem. 30, 579-583.

Lorimer, G. H. (1981) Biochemistry 20, 1236-1240.

Lorimer, G. H., \& Miziorko, H. M. (1980) Biochemistry 19, 5321-5328.

Lorimer, G. H., Badger, M. R., \& Andrews, T. J. (1976) Biochemistry 15, 529-536.

McCurry, S. D., Pierce, J., Tolbert, N. E., \& Orme-Johnson, W. H. (1981) J. Biol. Chem. 256, 6623-6628.

McGilvery, R. W. (1965) Biochemistry 4, 1924-1930.

Miziorko, H. M. (1979) J. Biol. Chem. 254, 270-272.

Pierce, J., Tolbert, N. E., \& Barker, R. (1980) Biochemistry 19, 934-942.

Rejda, J. M., Johal, S., \& Chollet, R. (1981) Arch. Biochem. Biophys. 210, 617-624.

Trown, P. W., \& Rabin, B. R. (1964) Proc. Natl. Acad. Sci. U.S.A. 52, 88-93.

Vater, J., \& Salnikow, J. (1979) Arch. Biochem. Biophys. 194, 190-197.

Wishnick, M., Lane, M. D., \& Scrutton, M. C. (1970) J. Biol. Chem. 245, 4939-4947. 